STRUCTURAL

CHEMISTRY

ISSN 2053-2296
Keywords: editorial; scorpionates; chemistry; crystal structure.

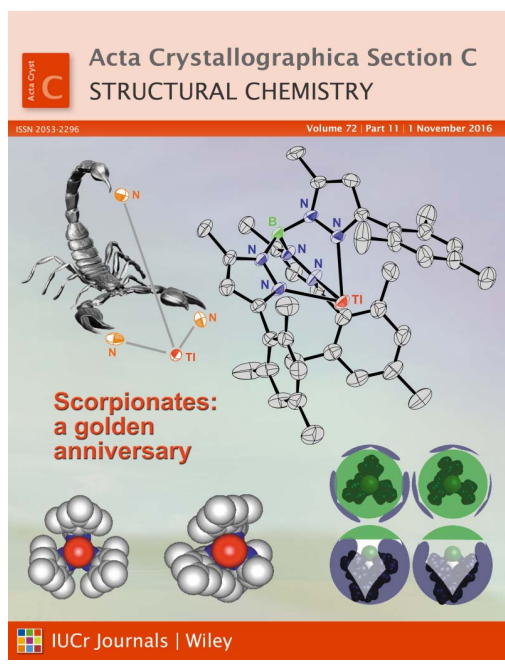

(C) 2016 International Union of Crystallography

\section{Scorpionate chemistry at the 50th anniversary}

\author{
Kiyoshi Fujisawa ${ }^{\mathrm{a} *}$ and Glenn P. A. Yap ${ }^{\mathrm{b} *}$ \\ ${ }^{a}$ College of Science, Department of Chemistry, Ibaraki University, 2-1-1 Bunkyo, Mito, Ibaraki 310-8512, Japan, and \\ ${ }^{\mathbf{b}}$ Department of Chemistry \& Biochemistry, University of Delaware, 236 Brown Laboratory, Newark, DE 19716, USA. \\ *Correspondence e-mail: kiyoshi.fujisawa.sci@vc.ibaraki.ac.jp, gpyap@udel.edu
}

The year 2016 marks the 50th anniversary of the discovery of scorpionates (Trofimenko, 1966), a class of tris(pyrazolyl)borate (Tp) ligands with proven versatility afforded by the ease of tuning the steric bulk and electronic properties at the metal coordination site. By adding bulky alkyl or aryl substituents, such as tert-butyl or phenyl, on the 3-position of the pyrazole, the second generation of scorpionates was introduced to discourage the formation of bis-ligand metal complexes, allowing new tetrahedral complexes to be synthesized (Calabrese et al., 1986). Functionalizing the fourth, noncoordinating, back position on the B atom opened new possibilities in third-generation scorpionates, such as magnetic behavior (Reger, 2005).

In 2013, the first special issue for Acta Crystallographica Section C was published, featuring scorpionates (Yap, 2013), and from the Editorial of that issue we quote 'The first book on scorpionates, 'Scorpionates: The Coordination Chemistry of Polypyrazolylborate Ligands', intended to provide a 32-year comprehensive coverage of $\mathrm{Tp}$ chemistry up to 1998 (including some 1999 papers), was published in 1999 (reprinted in 2005 ) with 1568 references cited (Trofimenko, 1999). The second book, 'Scorpionates II: Chelating Borate Ligands', was published in 2008 to cover research from 1999 to 2008, a much shorter nine-year period, with 1710 references cited (Pettinari, 2008). A study of common ligand metrics showed that $\mathrm{Tp}$ ligands had the largest population, at the time the study was conducted, for fac-coordinating triskelion (i.e. tripodal) ligands and were second largest only to cyclopentadienide ligands for all tridentate ligands (Aguila et al., 2009) ... A search on scorpionate structures in the Cambridge Structural Database (Version 5.34 of May 2013; Allen, 2002) yields 3480 hits, of which 59 appear in Acta Crystallographica journals.'

Roughly, this translates to about 74 structures annually averaged since inception. A search from 2013 onwards in the Cambridge Structural Database (Version 5.37, November 2015; Groom et al., 2016) yields 761 structures of which 21 appear in Acta Crystallographica journals.

Guest editor Kiyoshi Fujisawa's own chemistry research involves the use of hydrotris(pyrazolyl)borate to synthesize copper protein model complexes and to investigate polymerization catalysts. In copper protein model complexes, the $\mu-\eta^{2}: \eta^{2}$ copper(II) peroxide complex $\left[\left\{\mathrm{Cu}^{\mathrm{II}}\left\{\mathrm{HB}\left[3,5-(\mathrm{i}-\mathrm{Pr})_{2} \mathrm{pz}\right]_{3}\right\}\right\}_{2}\left(\mu-\mathrm{O}_{2}\right)\right]$ (Baldwin et al., 1992; Kitajima et al., 1992), the mononuclear copper(II) alkylperoxide complex $\left[\mathrm{Cu}^{\mathrm{II}}\left\{\mathrm{HB}\left[3,5-(\mathrm{i}-\mathrm{Pr})_{2} \mathrm{pz}\right]_{3}\right\}-\right.$ $\left.\left\{\mathrm{OOC}\left(\mathrm{CH}_{3}\right)_{2} \mathrm{Ph}\right\}\right]$ (Kitajima et al., 1993; Chen et al., 2000), and the mononuclear copper(II) side-on superoxide complex $\left[\mathrm{Cu}^{\mathrm{II}}\left\{\mathrm{HB}(3-t-\mathrm{Bu}-5 \text {-i-Prpz })_{3}\right\}\left(\mathrm{O}_{2}\right)\right]$ (Fujisawa et al., 1994; Chen et al., 2003) were structurally characterized, and the complexes $\left[\mathrm{Cu}^{\mathrm{II}}\{\mathrm{HB}[3,5-\right.$ $\left.\left.\left.(\mathrm{i}-\mathrm{Pr})_{2} \mathrm{pz}\right]_{3}\right\}\left\{\mathrm{O}_{2} \mathrm{C}(\mathrm{O}) \mathrm{C}_{6} \mathrm{H}_{4}-m-\mathrm{Cl}\right\}\right]$ (Kitajima et al., 1990) and $\left[\mathrm{Cu}^{\mathrm{II}}\left\{\mathrm{HB}(3-t-\mathrm{Bu}-5-\mathrm{i}-\mathrm{Prpz})_{3}\right\}-\right.$ $(\mathrm{OOH})]($ Chen et al., 2000) were physicochemically characterized using many techniques.

In addition to biochemical models, Fujisawa investigated scorpionates as ligands for catalyzed polymerization reactions of phenols by copper (Higashimura et al., 2000) and olefins by manganese (Fujisawa \& Nabika, 2013). Second-generation scorpionates are proving to be very useful in both research directions. In his research career, he has utilized hydrotris(pyrazolyl)borates, especially the $\mathrm{HB}\left[3,5-(\mathrm{i}-\mathrm{Pr})_{2} \mathrm{pz}\right]_{3}{ }^{-}$and $\mathrm{HB}(3-t-\mathrm{Bu}-5-$ i-Prpz $)_{3}{ }^{-}$ligands, and their derivatives, as the supporting ligands. He has published many articles reporting these scorpionates and therefore he attests that his research career has been significantly supported by scorpionates. In one of the papers in this special issue, he reports his research expanding second-generation scorpionates towards new ligand systems (Fujisawa et al., 2016). 
Recently, Pettinari has also celebrated the 50th anniversary of the discovery of scorpionates in another journal (Pettinari, 2016).

The papers in this special issue of Acta Crystallographica Section $C$ clearly show that scorpionate chemistry remains relevant, exciting, and productive. Perhaps the best words to conclude this editorial are from Jerry Trofimenko himself, written in 1992, but still true today: 'In the final analysis, the scorpionate field is wide open, and can be extended in almost any direction, being restricted only by the creativity of the scientist.' (Trofimenko, 1999).

\section{References}

Aguila, D., Escribano, E., Speed, S., Talancon, D., Yerman, L. \& Alvarez, S. (2009). Dalton Trans. pp. 6610-6625.

Allen, F. H. (2002). Acta Cryst. B58, 380-388.

Baldwin, M. J., Root, D. E., Pate, J. E., Fujisawa, K., Kitajima, N. \& Solomon, E. I. (1992). J. Am. Chem. Soc. 114, 10421-10431.

Calabrese, J. C., Trofimenko, S. \& Thompson, J. S. (1986). J. Chem. Soc. Chem. Commun. pp. 1122-1123.

Chen, P., Fujisawa, K. \& Solomon, E. I. (2000). J. Am. Chem. Soc. 122, 10177-10193.
Chen, P., Root, D. E., Campochiaro, C., Fujisawa, K. \& Solomon, E. I. (2003). J. Am. Chem. Soc. 125, 466-474.

Fujisawa, K., Kuboniwa, A., Kiss, M. \& Szilagyi, R. K. (2016). Acta Cryst. C72, 768-776.

Fujisawa, K. \& Nabika, M. (2013). Coord. Chem. Rev. 257, 119-129.

Fujisawa, K., Tanaka, M., Moro-oka, Y. \& Kitajima, N. (1994). J. Am. Chem. Soc. 116, 12079-12080.

Higashimura, H., Kubota, M., Shiga, A., Fujisawa, K., Moro-oka, Y., Uyama, H. \& Kobayashi, S. (2000). Macromolecules, 33, 1986-1995.

Kitajima, N., Fujisawa, K., Fujimoto, C., Moro-oka, Y., Hashimoto, S., Kitagawa, T., Toriumi, K., Tatsumi, K. \& Nakamura, A. (1992). J. Am. Chem. Soc. 114, 1277-1291.

Kitajima, N., Fujisawa, K. \& Moro-oka, Y. (1990). Inorg. Chem. 29, 358-360.

Kitajima, N., Katayama, T., Fujisawa, K., Iwata, Y. \& Moro-oka, Y. (1993). J. Am. Chem. Soc. 115, 7872-7873.

Pettinari, C. (2008). In Scorpionates II: Chelating Borate Ligands. London: Imperial College Press.

Pettinari, C. (2016). Eur. J. Inorg. Chem. pp. 2209-2211.

Reger, D. L., Gardinier, J. R., Gemmill, W. R., Smith, M. D., Shahin, A. M., Long, G. J., Rebbouh, L. \& Grandjean, F. (2005). J. Am. Chem. Soc. 127, 2303-2316.

Trofimenko, S. (1966). J. Am. Chem. Soc. 88, 1842-1844.

Trofimenko, S. (1999). In Scorpionates - The Coordination Chemistry of Polypyrazolylborate Ligands. London: Imperial College Press. Yap, G. P. A. (2013). Acta Cryst. C69, 937-938. 